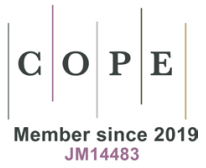

\title{
Venice in Poetry and Prose: Adam Wiedemann's Visit to the City
}

\section{S U M M A R Y}

The main aim of the article is to identify key interpretation issues in two texts by Adam Wiedemann. Both texts feature contemporary literary pictures of visits to Venice - the Polish author wrote a short story (Sens życia. Opowiadanie śródziemnomorskie, 1998) and a poem (Tramwaj na Lido, 2015) about his journeys to Italy. Those textual visions of the urban space of Venice show that Wiedemann is fully aware of many similar attempts made earlier yet still strives to stress his distinctness, creating a record of meetings of the contemporary visitor with the unique phenomenon of the unusual urban phenomenon.

\section{Keywords}

Venice, city, spectre, palimpsest, Adam Wiedemann

Venice is a well-known city, recognisable at first sight and crowded with visitors. At the same time, it is sometimes perceived as a city associated with decay, old age and death: it continues to last - exposed to extinction and destruction - yet it can be swept away from the surface of the earth (by water) at any time. In his text titled "On The Uses and Disadvantages of Living Among Specters," Giorgio Agamben argues that Venice has long since acquired the status of a spectre, or rather a collection of palimpsestically 
overlapping spectres, each of which is made up of signatures that time engraves on the surface of things:

A specter always carries with it a date wherever it goes; it is, in other words, an intimately historical entity. This is why old cities are the quintessential place of signatures, which the flaneur in turn reads, somewhat absentmindedly, in the course of his drifting and strolling down the streets. This is why the tasteless restorations that sugarcoat and homogenize European cities also erase their signatures; they render them illegible. And this is why cities - and especially Venice - tend to look like dreams. ${ }^{1}$

Immersion in the signs of time preserved in the space of cities becomes a special act of cognition, during which attempts are made to penetrate their spectral essence and efforts are made to transcend this essentially elusive phenomenon.

Venice resisted historical turmoil for a long time. In her volume published in London during the war in 1940 (titled meaningfully Róża i lasy płonace [A Rose and Burning Forests]), Maria Pawlikowska-Jasnorzewska featured a poem titled "Wenecjo" [Oh, Venice]..., which is her special farewell to the city:

Do dziś jeszcze nietknięta koronko

[kamienna!

Żegnam cię, boś zbyt piękna. Nie dzisiaj, [to jutro,

Nie ta wojna, to inna. Jużeś dla mnie [widmem... ${ }^{2}$

\author{
Oh, stone lace intact to this day! \\ I take leave, as you are too fine. Not today, \\ [then tomorrow, \\ Not this war, then another. You're already \\ [a spectre to me.
}

'Lacey' (fragile, ephemeral, phenomenal) Venice, despite being made of stone (which is a durable, time-resistant material), has become a lyrical sign of the disintegrating European order, its cultural trace, but it continues to exist, albeit merely as its spectre, while other cities were consumed by fire similar to that which destroyed Pompeii. The annihilation of Venice - expected and foretold many a time - is thus tantamount to the slow dying out of its vitality, the erosion of the walls, the disintegration of the foundations. Speaking about it - freezing the image of the city in words - involves evoking the extraordinary, unique, spectral beauty that grew out of centuries of

${ }^{1}$ Giorgio Agamben, "On The Uses and Disadvantages of Living Among Specters," in Nudities, (Stanford: Stanford University Press, 2011), http://www.carouselvenezia.eu/letture/ giorgio-agamben-cadaverous.html.

${ }^{2}$ Maria Pawlikowska-Jasnorzewska, Poezje zebrane, vol. 2, ed. Aleksander Madyda (Torun: Aldo, 1993), 7. The work also presents the anxiety caused by the feeling of the city's imminent destruction: "O dworzyszcza syrenie, z ciemną wodą w progu, / Z gwiazdą kraba pod oknem! Drżę o was czarowne, / Byście nie runęły gruzem kolumn, fasad" [Oh mermaid courts, with dark water at the doorstep, / With a crab star at the window! I tremble for you, adorable, / So that you do not fall with the debris of columns, fa HYPERLINK "https://translatica.pl/translatica/po-polsku/facade;385945.html" çades]. [Unless indicated otherwise, quotations in English were translated from Polish] 
tradition and the bitter awareness that it is constantly exposed to irreversible destruction.

In the introduction to the collection of critical sketches titled Poczytalność. Przygody literackie [Readership. Literary Adventures], Adam Wiedemann presented his vision of the literary text and its relationship with the reality. As the author argued, it is not only the relationship between a word and its designates or between a word with other words that are important to him:

I therefore need to have an idea about the relationships of the relationships between words and the relationships of designates which are completely independent from the words; it is an enigma, and it is an abyss I like to fall into for I know that it is easy to get out of this particular abyss with the proverbial fish in equally proverbial (although less and less natural) teeth. I have this bite and there is always some species of fish that is willing to fall into it. ${ }^{3}$

The conviction of the existence of such multifaceted and multi-level ties between words and designates provokes Wiedemann to arrive at a conclusion: "Literature seeks to communicate with the truth it creates," hence it is in the course of artistic explorations that the 'truth' created within their framework can be found and grasped.

The Shakespearean 'creation' of Venice in verse appeared, in fact, to break down its image as the political and economic power of the Renaissance era, the steadfast queen of sea routes: Venice is, above all, a place where the transitoriness of all human illusions and delusions is revealed, and where the masks hide rotting, death and an inherent sense of unfulfillment. Antonio of Venice, the protagonist of The Merchant of Venice, spoke about it with conviction:

I hold the world but as the world, Gratiano,

A stage where every man must play a part,

And mine a sad one. ${ }^{5}$

Appearances, which rule the world, cause sadness, while wealth, superfluity and success reveal their fleeting nature. In his study of Shakespeare's play titled Theater of Envy: William Shakespeare, René Girard stresses that "Venice is a world where presentation and reality do not match (...) an astute Venetian knows very well how deceptive the wonderful superficiality can be." ${ }^{\prime 6}$ In turn, the protagonist of the story about the fate of the Venetian Moor expresses his conviction that all social and legal rules of life are fragile and fleeting - Iago's words contradict the importance of the legal and

${ }^{3}$ Adam Wiedemann, Poczytalność. Przygody literackie (Wrocław: Warstwy, 2016), 10.

${ }^{4}$ Wiedemann, Poczytalność. Przygody literackie, 11.

${ }^{5}$ William Shakespeare, The Merchant of Venice, Act 1, Scene 1, https://www.opensourceshakespeare.org/views/plays/play_view.php?WorkID=merchantvenice\&Act $=1 \& S c e n e=1 \&$ Scope=scene (accessed on: 5.10.2020).

${ }^{6}$ René Girard. Teatr zazdrości, trans. B. Mikołajewska (Warsaw: KR, 1996), 311, trans. mine. 
religious foundations of everyday existence: "if sanctimony and a frail vow betwixt an erring barbarian and a supersubtle Venetian be not too hard for my wits and all the tribe of hell, thou shalt enjoy her." ${ }^{\prime 7}$ Comforting Othello's defeated rival, who lost his chance (in his opinion only temporarily) to have a relationship with Desdemona, he repeated to him many a time, like a mantra, his good advice in all circumstances of life: "fill thy purse with money," although he too soon learnt that a full purse and skillful intrigue would not be able to save even the most cunning and far-sighted man from falling.

In the city's heyday, both the principles of community life and transparent social hierarchies built on the basis of financial position seemed to be inviolable. Using wealth to multiply everyday pleasures used to be accompanied by the desire to make it visible in every form available. In his text titled "Fear of Touching: The Jewish Ghetto in Renaissance Venice," Richard Sennet notes that "The basic element in the image of Venice - both in the eyes of Europe and the Venetians themselves - was sensuality. The splendid palaces along the Grand Canal had richly decorated façades, their colours reflected in the water" ${ }^{\prime \prime}$. However, in the end, all debauchery reveals its (self-) destructive power: interpreting The Merchant of Venice, Sennet argues that it is a story about the liberation of man from the burden of culture, and with the end of art we enter the modern world ${ }^{10}$. Paradoxically, the 'sensual' city, rich and full of superfluous space for show, could be treated as a blurred, less and less readable sign of the old order, a decorative façade covering the disintegration, a mask concealing the inherent evil of human nature.

In his volume Sęk Pies Brew [A Knot, a Dog, an Eyebrow], Adam Wiedemann published "five short literary pieces" (the title refers phonetically to the French version of the content description of the collection). The stories published in 1998 are primarily a special play with tradition. The last one, provocatively titled Sens życia [The Meaning of Life], has an equally perverse subtitle, namely Opowiadanie śródziemnomorskie [The Mediterranean Story]. In this case, a 'journey to Italy' - 'sacred' in the records of many predecessors - becomes a casual hitchhiking trip, and the young protagonists, loaded with backpacks, want above all to have a nice time, not wasting it on visits to museums and galleries or sightseeing (activities otherwise exceeding their limited financial possibilities). The 'meaning of life', which was previously sought after by wanderers from Italian trails, turns out in the story to be a variety of shiny objects: cleverly inserted by

7 William Shakespeare, The Tragedy of Othello, the Moor of Venice, Act 1, Scene 3, https://www.opensourceshakespeare.org/views/plays/play_view.php?WorkID=othello\&Act=1\&Scene=3\&Scope=scene (accessed on: 5.10 .2020$)$.

${ }^{8}$ Shakespeare, The Tragedy of Othello, the Moor of Venice, Act 1, Scene 3.

${ }^{9}$ Richard Sennet, "Lęk przed dotykiem. Żydowskie getto w renesansowej Wenecji," in: Ciało i kamień. Człowiek i miasto w cywilizacji Zachodu, trans. M. Konikowska (Gdańsk: Wydawnictwo Marabut, 1996), 179.

${ }^{10}$ Sennet, "Lęk przed dotykiem. Żydowskie getto w renesansowej Wenecji," 201. Richard Sennet stresses that the establishment of the ghetto in Venice was accompanied by a change in the status of the urban 'organism'; from that time on the 'city' began to denote "a legal, social and economic creation which is too large and too diversified to be able to unite people" (183). It was in Venice that the first fully isolated ghetto for Jewish inhabitants was established. 
'modern artists' in their installations or bought in street stalls as fugitive holiday souvenirs.

In his short stories (including those from the previous volume titled Wszędobylstwa porzadku [The Ubiquity of Order]), Wiedemann reconstructs the special aura of the last decade of the 20th century: here young travellers relish the very opportunity to move around in previously inaccessible lands. The lack of sufficient resources proves to be an inconvenience forcing people to give up traditional behaviour and confine themselves to superficial encounters with new places on their route, which, however, allows for all forms of self-restraint rather than cause frustration. In his text titled "Horror metaphysicus czyli banalizm rzekomy" [Horror Metaphysicus or Supposed Banality], Arkadiusz Morawiec argues that Wiedemann did not deal with the banality of everyday experience in his texts but with the intellectual reflection on its inevitability. According to Morawiec, he presented a rather special youthful cognitive optimism, testifying that even when we are adults, we do not want to get rid of childish naivety, namely:

The temptation to explain the world ambivalently treated in Wiedemann's prose - to see it as 'constructed', purposeful, as a secret code, to which we stubbornly try to find the key. Even when the hieroglyphs are: a cassette tape, a trip to a shop, a handle in a toilet, a gadget shining in cold light. ${ }^{11}$

Thus, the apparent, 'sincere' naivety turns out to be a concept, allowing both the description of the world and its (conditional, partial, temporary) ordering.

Encounters with art - as if 'obligatory' during Italian trips - have a special course in Wiedemann. In Padua, young people take advantage of a free screening of student film etudes and an art exhibition. In the background one can hear amateur orchestra playing Vivaldi. Later, they decide to watch more 'avant-garde' projects, small rooms with artistic installations hidden in them (this is what the central part of the story, entitled Monstra [Monsters], is about). The experience of that day, however, primarily arouses a desire to crack jokes, play and even mock the 'works of art' which they watched. In addition, all their choices are to a large extent conditioned by the need to carry heavy backpacks and look for the cheapest accommodation and free means of transport. In such conditions, the 'barbaric' trip becomes an end in itself as a fully accepted model for spending holidays together (because finally available).

The third part of Opowiadanie śródziemnomorskie, titled Wenecja [Venice], begins with the image of the characters (with their inseparable backpacks) waiting in St Mark's Square for the rest of the scattered group of hitchhikers:

This time we chose as a meeting point the winged lion standing on a pole in St. Mark's Square (...) In the end, we began to wonder if we should not hang the white-and-red flag and proclaim a Polish colony on this area under the lion (fenced with thick chains), which would cause an unavoidable

${ }^{11}$ Arkadiusz Morawiec, Horror metaphysicus czyli banalizm rzekomy. Uwagi o prozie Adama Wiedemanna, http://culture.pl/pl/artykul/horror-metaphysicus-czyli-banalizm (accessed on: 5.10.2020). 
intervention of the Carabinieri and, consequently, resonance in the local press and beyond, and after the (probably forced, and thus free) return to the country, medals and honours would be already awaiting us. ${ }^{12}$

'Dreaming of fame' is, however, only a temporary project to kill time, a way of surviving in unfavourable conditions.

The last sentence of the story apparently looks like its pathetic coda: "A storm broke out at night, and four orchestras, filling the air over San Marco with their casual aleatoric buzzing, went quiet with unexpected unanimity and after a while, only the wind was hurling white papers and rags across the dark square"13. However, this short text is accompanied by two pages of footnotes, which are a faked and derisive 'deepening' of the travel observations and philosophical reflections on the 'meaning of life' written in it. The last footnote to the last sentence says: "After such a sentence, each subsequent one would really be something inappropriate."14 In this way, the account of the summer expedition understood by young Poles at the end of the 20th century turns out to be a kind of literary joke and, at the same time, a testimony to the change of perspective in the perception of foreign travels devoid of Eastern European complexes, emigrant occurrences or xenophobic stereotypes.

A visit to a place like Venice even demands to be written down as if the uniqueness of the city induced the visitor to leave a trace which would be personal yet determined by previous descriptions of the experience. Polish post-war variants of such stories lie between testimonies of absolute fascination and total disavowal of the cultural rank of the place, considered to be one of many similar (and likewise foreign) places. The uniqueness of the city was beyond any doubt for Gustaw Herling-Grudzinski. In the short story titled "Portret wenecki" [A Venetian Portrait] from the volume Goracy oddech pustyni [The Hot Breath of the Desert], Venice appears as it appeared to the eyes of a wartime castaway "with the unparalleled elegance, dignity and mysterious loftiness of an untouchable creature, a city so proud that there is no daredevil capable of raising his hand to it." ${ }^{15}$ Beauty saved from the war calamity could be seen as a value capable of resisting evil.

The meeting with the city was described by the narrator as "a love initiation into Venice":

Each day I fell more and more for the city, which the poet describes as built of dreams and which I admired for its special relationship, one might say: for the marriage of dreams with reality (...) I quickly came to terms with the fact that even if I lived here or often came here over many years, I would never break through to the heart of Venice as it happens in other cities. For it is not there. ${ }^{16}$

\footnotetext{
${ }^{12}$ Adam Wiedemann, Sęk Pies Brew (Warsaw: W.A.B., 1998), 134.

${ }^{13}$ Wiedemann, Sęk Pies Brew, 135.

${ }^{14}$ Wiedemann, Sęk Pies Brew, 137.

${ }^{15}$ Gustaw Herling-Grudziński, "Portret wenecki," in Goracy oddech pustyni (Warsaw: Czytelnik, 1997), 99.

${ }^{16}$ Herling-Grudziński, "Portret wenecki," 100.
} 
The inability to reach the (non-existent?) heart of the city was considered an advantage, and the cognitive limitations were deemed the ultimate proof of its uniqueness. The narrator of the story, who lives in the house of a restorer of Renaissance paintings by Venetian painters, had the opportunity to see the process of copying, reproducing, reconstructing - and thus falsifying - the works of the old masters.

In later years, this emigrant, thrown into the unacceptable realities of London's peripheral district, was forced to "evoke images of Venice on a piece of dilapidated and dirty wall"17 and in that way he managed to survive the several years that separated him from his departure for Italy, where he finally settled for good. He succeeded in achieving the status of an art expert and connoisseur of the past, and, in a way, blended into the cultural landscape of Italian tradition. Eventually, however, the city on the lagoon also revealed its ambiguity in this story, because as it turned out in the ending of "Portret wenecki," capturing the essence of the Evil of the war and at the same time transforming it into a beautiful painting, into true - though at the same time falsified - Art, was possible precisely in Venice.

A completely different picture of a visit to Venice can be found in the grotesque approach of Sławomir Mrożek. The protagonist of the short story titled "Moniza Clavier," a modern barbarian, shows no interest in the city in which he finds himself for an unknown reason. He had no business to do in Venice (nor, as he admitted, anywhere else), and at no time was he interested in sightseeing. He simply walked through the streets, pretending to be in the right place at the right time, angry at everything that was different or alien, cursing the unknown and creating melancholy images of 'the familiar': "I was seething with anger. They planted the palm trees but they seem unable to make a decent footpath. In our country this is different. There are no palms here, but the pavements are fine."18 These were compensatory measures on his part allowing him to ignore the uniqueness of Venice: the protagonist only sometimes admitted to his sense of inferiority, although he did so only to himself: "I was walking around Venice to my distress, as it was a bold walk, making me feel more and more feeble and insipid."19

The feeling of incomprehensible superiority gave him, for some time, the possession of a stock of kabanos sausages brought by him from his homeland, which he had been feeding on since his arrival. After some time, however, this activity was no longer a consolation either and he was forced to admit that "in the face of the lagoon, with black gondolas tossed by waves in front of them and the Doge's Palace behind my back, I was eating that kabanos sausage in a cursed marriage with it." ${ }^{20}$ The sight of another,

\footnotetext{
${ }^{17}$ Herling-Grudziński, “Portret wenecki," 116. The record of everyday life in a wretched London apartment building was created by contrast: "as our life in the dark room was becoming a nightmare, short-lived euphoric delusions multiplied before my eyes. Later, the phenomenon went beyond our tenement house and I happened to succumb to similar illusions in the ugly and shabby streets soaked in the yellow light of lampposts" (116).

${ }^{18}$ Sławomir Mrożek, "Moniza Clavier. Romans," in Opowiadania 1974-1979 (Warsaw: Oficyna Literacka Noir sur Blanc, 1995), 147.

${ }^{19}$ Mrożek, "Moniza Clavier. Romans," 170.

${ }^{20}$ Ibid., 155.
} 
magnificent 'foreign' sausage, revealing the misery of the food brought from Poland turned out to be the final blow:

weary - despite my refractory youth - dragging my legs and no longer trying to keep up appearances, I saw giant gammon hanging from a hook in front of the butcher's. It was of such magnitude that it was likely to serve not only advertising but also metaphysical purposes. The triumph of frenzied sausaginess which goes beyond itself. ${ }^{21}$

After many attempts to find himself in a foreign space, this resident of a small country in the East of Europe who pretended to be a Russian was condemned to miserable vegetation in a world which he did not even try to understand. A short-lived social success, achieved through the role of a barbarian played by him with bravado, remained only a dream ${ }^{22}$, which he could feed on in later years of emigrant misery.

Only strangers who are open, if only partially, to the uniqueness of Venice, can fall in love with the City or otherwise just 'score' it - conquer and include it in the catalogue of memories. ${ }^{23}$ The situation of inhabitants growing up in the shadow of an unusual place which functions as a special landmark on every tourist map is different. Giorgio Agamben even expressed his conviction that Venetians are incapable of loving their city:

They do not know that they can love it for it is difficult to love the dead. It is easier to pretend that it is alive, to cover its fragile and bloodless parts with masks and lipstick so as to show them to tourists for a fee [..] And it is, after all, about the spectre, that is to say, if it knows that it is a spectre, a thing that is extremely ethereal and airy, infinitely distant from the corpse. ${ }^{24}$

${ }^{21}$ Mrożek, "Moniza Clavier. Romans," 156. The meeting with the extraordinary 'sausaginess' determined the fate of the protagonist: "The kabanos sausage was of no avail (...) The weapon was thrown out of his hand. There was no other alternative but to throw oneself blindly into this world, to fight with it hand to hand, to defeat it or to die" (Mrożek, "Moniza Clavier. Romans," 156).

${ }^{22}$ After one of the more successful parties, the protagonist recorded: "And it was a feast of lovers. I was in love with Europe, Europe with a Russian, and the Russian - you do not know because he was not there." (Mrożek, "Moniza Clavier. Romans," 178).

${ }^{23}$ Cf. Anna Wieczorkiewicz, Apetyt turysty. O doświadczaniu świata w podróży (Krakow: Universitas, 2012). The ambiguity of the term 'score' shows the ambivalence of modern tourist activities: this could mean both the compulsion to 'tick' new places off the list, places which are considered fashionable and an absolute 'must-see' at the time, and the brevity of such contact, being a denial of any deeper feelings.

${ }^{24}$ Giorgio Agamben, "On The Uses and Disadvantages of Living Among Specters," 49-50. The philosopher argues that our times, designed as the 'latest', are at the same time the 'last' and therefore posthumous and phantasmal: "That is why we see a parade of skeletons and mannequins with their breasts outstretched, and why we see mummies trying carelessly to control their exhumation without noticing that they are losing pieces and shreds of their decaying limbs and that their words sound like incomprehensible gibberish. The spectre of Venice does not know about all this at all. The Venetians could not see it, and certainly not tourists" (52). Trans. mine. 
However, if the inhabitants lost the ability to form an authentic bond, it may be because of the overwhelming burden of countless stories about 'their' city (constantly appropriated by strangers), from underneath which it is difficult to reveal its 'real' image, authentic experience, the matter of real existence. The protagonist of Invisible Cities by Italo Calvino (published in 1972), referred to as Marco Polo or the Venetian, confided in the character called Kublai Khan: "Every time I describe a city I am saying something about Venice." ${ }^{25}$ Hence, he admitted that it is the place of birth that represents the prism through which every space experienced later is perceived. He knew, however, that the story could become a special veil for memories, and he argued with conviction: "Memory's images, once they are fixed in words, are erased." 26

In a poem written in the 2010s titled "Tramwaj na Lido" [A Tram to the Lido], Adam Wiedemann showed this specific state of suspension between the memory enclosed in countless stories about the history of the city and its falsified 'life' for use of foreigners:

\author{
W mieście nic się nie dzieje, \\ dzianie się jest odziane \\ $\mathrm{w}$ te żmudnie wydziergane \\ przez protoplastów koleje \\ losu, po których płyną \\ i dziwnie w nich nie toną \\ ani się dławią słoną \\ wodą jakby odwinął
}

się znad ryby pergamin

i zamoczywszy w wodzie

dłoń, starano się nią

objąć cały stól, co dzień

zastawiony źródłami,

które też dokądś brną. ${ }^{27}$
In the city nothing happens,

happening is dressed

in the ancestors' painstakingly

knitted turns

of fate on which they sail

and oddly enough never sink in them

or suffocate with salty

water as if parchment

unwrapped from above the fish

and having soaked a hand

in the water, trying to use it

to embrace the whole table laid

with springs each day,

which also wade somewhere.

The poem is also marked with the date, namely 1.08.15, and contains a vision of a city determined by its own past. An image enclosed in the recognisable framework of a sonnet still considered to be 'elaborate,' reveals the repetition of arduous (and hence boring) activities, primarily aimed at recreating the rituals invented by the 'ancestors.' The rhythm of everyday

\footnotetext{
${ }^{25}$ Italo Calvino, Invisible Cities, trans. William Weaver, accessed October 7, 2020 https:// www.goodreads.com/work/quotes/68476-le-citt-invisibili.

${ }_{26}$ Calvino, Invisible Cities. Subsequently, Marco Polo pinpoints his own concerns: "Perhaps I am afraid of losing Venice all at once, if I speak of it, or perhaps, speaking of other cities, I have already lost it, little by little," https:/www.goodreads.com/work/ quotes/68476-le-citt-invisibili (accessed on: 7.10.2020).

${ }^{27}$ Adam Wiedemann, Tramwaj na Lido, http://www.poecipolscy.pl/poezja/prezentacja/ adam-wiedemann
} 
life, once determined by their decisions, serves the purpose of playing a spectacle of extraordinary life rather than really experiencing it. Looking for traces of novelty (or even 'modernity') in Venice seems to be an activity which is not so much meaningless as it is inappropriate.

Trying to penetrate the phenomenon of the city's durability in spite of all external and internal adversities, the writer perceives the theatrical (theatricalised) repetition of everyday activities as a way of swimming (in circles) without sinking. An expedition to Venice in search of variety or current fashionable attractions would have to meet with failure. In the end, however, staying in a city infected with death and threatened with extinction may help familiarise one with the inevitability of passing away. After all, Aschenbach found out about this already at the beginning of the 20th century, since in his case the last, ante-mortem visit to Venice was a particular challenge, consisting in overcoming old weaknesses combined with a constant, though already impossible, desire to depart:

When Aschenbach opened his window he thought he smelt the stagnant odour of the lagoons. He felt suddenly out of sorts and already began to think of leaving. Once, years before, after weeks of bright spring weather, this wind had found him out; it had been so bad as to force him to flee from the city like a fugitive. And now it seemed beginning again-the same feverish distaste, the pressure on his temples, the heavy eyelids. ${ }^{28}$

Nonetheless, the willingness to flee passes once you realise that there is, in fact, no rescue from the approaching end of life.

Venice as a telltale sign of the inevitable annihilation of civilisation can also be seen as a warning, the understanding of which is capable of turning things around. In his article titled "Wenecja jako widmo" published in 2013 Dariusz Czaja argues:

Maybe the Venetian spectre circulating over Europe can be at least partially tamed, or maybe it can make life with it somehow possible. And one more thing. It cannot be ruled out that the spectral Venice is a sign that we are still unable to read. Perhaps some important information is recorded not only in the Venetian palaces, but also in the despised Venetian 'wastelands.' 9

Nowadays, however, the need to read signs, listen to warnings and explore the secrets of destiny is disappearing both in individual and collective life. Sliding on the surface of phenomena and places makes it easier to accept the everyday reality, pushing away the need to ask questions about the future.

\footnotetext{
${ }^{28}$ Thomas Mann, "Death in Venice," in Death in Venice and Seven Other Stories, trans. Helen Tracy Lowe-Porter (New York: Random House, 1989), 27.

${ }^{29}$ Dariusz Czaja, "Wenecja jako widmo," in: Inne przestrzenie, inne miejsca. Mapy i terytoria, ed. Dariusz Czaja (Wołowiec: Wydawnictwo Czarne, 2013), 142.
} 
The reluctance to read the traces of the past also lies at the root of a general retreat from the palimpsestic perception of space. In her book from 2019 titled Pytania o miejsce [Questions about Place], Elżbieta Dutka, summing up the findings of many contemporary researchers, states that:

The figure of the palimpsest also signals a certain order, assumes that - notwithstanding its discontinuity - it is possible to indicate what belongs to the earlier layers that only shine through, and what belongs to the later ones, what refers to the real space, and what is part of the layer of cultural memory. However, separating the layers proves difficult or even impossible on many occasions. ${ }^{30}$

The inability - or even more so the feeling of redundancy to make another effort to separate the layers of meaning, to penetrate their senses, to explore their mutual relations - leads to a common perception of heterogeneity of space or hybridity of places, and at the same time to considering them as illegible or even not worth reading. From this perspective, Venice may be seen as a beautiful but empty model of the past, and the destruction looming over it may turn out to be just another piece of information in the media that does not arouse much interest among the public.

The literary records of Adam Wiedemann's meetings with Venice can be interpreted as significantly different since the gestures of establishing contact with otherness closed in the urban phenomenon belong to different epochs in both the author's biography and the social history. In such an approach, it seems rather natural for the artist to move from the perspective of a young 'barbarian' to a mature, illusion-free 'connoisseur of tradition'. However, in this case, another aspect of artistic research seems to be more important, namely checking the limits of the expressiveness of literature (the constant writing about those "relationships of the relationships between words and the relationships of designates which are independent from the words"). Saying something 'new' about Venice seems impossible today: therefore perhaps it is enough to try to say 'something more' from oneself?

\section{REFERENCES}

Agamben, Giorgio. "On The Uses and Disadvantages of Living Among Specters." In Nudities. Stanford: Stanford University Press, 2011. Accessed October 5, 2020. http://www.carouselvenezia.eu/letture/giorgio-agamben-cadaverous.html.

Calvino, Italio. Invisible Cities. Translated by William Weaver, Warsaw 1975. Accessed October 7, 2020. https://www.goodreads.com/work/ quotes/68476-le-citt-invisibili.

${ }^{30}$ Elżbieta Dutka, Pytania o miejsce. Sondowanie topografii literackich XX $i$ XXI wieku (Krakow: Universitas, 2019), 200. 
Czaja, Dariusz. "Wenecja jako widmo." In: Inne przestrzenie, inne miejsca. Mapy i terytoria, edited by Dariusz Czaja, 123-142. Wołowiec: Wydawnictwo Czarne, 2013.

Dutka, Elżbieta. Pytania o miejsce. Sondowanie topografii literackich XX i XXI wieku. Krakow: Universitas, 2019.

Girard, René. Szekspir. Teatr zazdrości. Translated by Barbara Mikołajewska, Warsaw: KR, 1996.

Herling-Grudziński, Gustaw. "Portret wenecki." In Goracy oddech pustyni, 90-127. Warsaw: Czytelnik, 1997.

Mann, Thomas. "Death in Venice." In Death in Venice and Seven Other Stories. Translated by Helen Tracy Lowe-Porter, 27. New York: Random House, 1989.

Morawiec, Arkadiusz. Horror metaphysicus, czyli banalizm rzekomy. Uwagi o prozie Adama Wiedemanna. Accessed October 5, 2020. http://culture.pl/pl/artykul/horror-metaphysicus-czyli-banalizm. [access: 15.12.2019]

Mrożek, Sławomir. "Moniza Clavier. Romans." In Opowiadania 1974-1979, 146-192. Warsaw: Oficyna Literacka Noir sur Blanc, 1995.

Pawlikowska-Jasnorzewska, Maria. Poezje zebrane, vol. 2. Edited by Aleksander Madyda. Torun: Aldo, 1993, 7.

Sennet, Richard, "Lęk przed dotykiem. Żydowskie getto w renesansowej Wenecji." In Ciało i kamień. Człowiek i miasto w cywilizacji Zachodu. Translated by M. Konikowska, 171-201. Gdańsk: Marabut, 1996.

Shakespeare, William. The Merchant of Venice. Accessed October 5, 2020, https://www.opensourceshakespeare.org/views/plays/play_view. php? WorkID $=$ merchantvenice $\& A c t=1 \& S$ cene $=1 \& S$ cope $=$ scene.

Shakespeare, William. The Tragedy of Othello, the Moor of Venice. Accessed October 5, 2020. https://www.opensourceshakespeare.org/views/plays/ play_view.php?WorkID=othello\&Act $=1 \& S$ cene $=3 \&$ Scope $=$ scene.

Wieczorkiewicz, Anna. Apetyt turysty. O doświadczaniu świata w podróży. Krakow: Universitas, 2012.

Wiedemann, Adam. Poczytalność. Przygody literackie. Wrocław: Warstwy, 2016, 10.

Wiedemann, Adam. Sęk Pies Brew. Warsaw: W.A.B. 1998.

Wiedemann, Adam. Tramwaj na Lido. Accessed October 5, 2020. http://www. poecipolscy.pl/poezja/prezentacja/adam-wiedeman [access: 6.01.2020].

Agnieszka Czyżak - dr hab., professor of Adam Mickiewicz University, Department of Literary Poetics and Criticism, Institute of Polish Philology, Adam Mickiewicz University in Poznań. She focuses on modern literature, mainly works written since 1989. She co-edited collective works, e.g.: Powroty Iwaszkiewicza (1999), PRL - świat (nie)przedstawiony (2010), Pokolenie "Wspótczesności". Twórcy. Dzieła. Znaczenie (2016). She is the author of the books: Życiorysy polskie 1944-1989 (1997), Kazimierz Brandys (1998), Na starość. Szkice o literaturze przełomu tysiącleci (2011), Świadectwo rozproszone. Literatura najnowsza wobec przemian (2015), Przestrzenie w tekście, w przestrzeni tekstów. Interpretacje (2018), Pasja przemijania, pasja utrwalania. O dziennikach pisarek (2019, co-authors: B. Przymuszała, A. Rydz), and Przeciw śmierci. Opowieść o twórczości Wiesława Myśliwskiego (2019).

E-mail: agaczyz@amu.edu.pl 